\title{
TCOM \\ China and the battle to win the scientific narrative about the origin of COVID-19
}

\section{Daniel Lemus-Delgado}

\begin{abstract}
The emergence of COVID-19 represented a critical problem for the legitimacy and prestige of the Chinese Communist Party. The Chinese authorities had to fight not only to contain the spread of the virus but also to create a favorable public opinion about how they managed the crisis. Based on Foucault's approach to the "Regime of Truth", this article analyzes the narrative surrounding the origin of the virus and how science was employed to lend it legitimacy. The article concludes by reviewing how the idea of science as a truth knowledge is used to construct a particular viewpoint, one focused on legitimizing the outbreak containment measures taken by the Chinese government.
\end{abstract}

Keywords

DOI

Introduction: a new virus on the horizon and the legitimacy problems of the Chinese Communist Party
Public perception of science and technology; Representations of science and technology; Science and media

https://doi.org/10.22323/2.19050206

Submitted: 28th June 2020

Accepted: 14th August 2020

Published: 30th September 2020

In January 2019, Xi Jinping, Secretary-General of the Chinese Communist Party (PCC) and President of the People's Republic of China (PRC), warned in a discourse at the Central Party School that Chinese security and stability were being subjected to multiple threats. According to Xi, China should be prepared to face unpredictable events in a complicated and delicate international context. He warned senior PCC officials that they should be on high alert for two types of incidents. Some of these incidents Xi referred to as "black swans", while others were referred to as "gray rhinos". For Xi, rhinos correspond to known risks that are underestimated, while black swans are highly unforeseen events. Xi asked party officials to "be on guard against black swans and be watchful for gray rhinos." [Lam, 2019].

One year later, the PCC leadership would be widely challenged by the emergence of a black swan. In Wuhan City, a new strain of coronavirus emerged that had not previously been identified in humans. This virus would test the ability and leadership of the Chinese bureaucratic elite to deal with a health emergency. The 
new virus was named by the World Health Organization Sars-Cov-2 [World Health Organization, 2020]. Although in 2003 the Chinese government had already dealt with a health crisis stemming from another respiratory disease, SARS, the new coronavirus posed an even greater threat due to its rapid spread, its diverse forms of infection, and its high case-fatality rate [Szabo, 2020]. In addition, the new virus emerged at the worst possible time of the Chinese year: the days leading up to the Lunar New Year. Airports, train stations, bus stations, and the transport networks of entire cities were under immense pressure as Chinese citizens make an estimated 3 billion trips over this period [Bloomberg, 2020]. The mass movement of millions of people was the worst possible context for the emergence of the new virus because it would allow blanket dispersal throughout the country. What was a serious problem in the Hubei region was highly likely to spread unchecked throughout the entire nation.

The initial response of the provincial government in Hubei was slow and erratic. Local authorities even went as far as to threaten health professionals who warned that there was a possible SARS-like outbreak at Wuhan Central Hospital. The municipal government not only ignored the warning signs but also took measures to conceal the emergence of an epidemic, censor information, and repress those who reported the growing number of patients [Li, 2020]. This reaction on the part of the local authorities generated enormous social unrest, not only in Wuhan but throughout China. The resulting tension exploded on social networks, causing distrust, anger, and frustration among the population [Davidson, 2020], and ultimately coming to represent a serious threat to the legitimacy of the Chinese Communist Party (CCP) [Rezková and Šimalčík, 2020].

As the virus spread however, the Chinese government changed its attitude. The central authorities took control of the crisis [Tian and Lee, 2020] and an aggressive program was launched to contain the virus. Once it appeared that the battle to tame the virus had turned a corner, another challenge became apparent: that of creating a favorable public opinion towards how the Communist Party had dealt with the health crisis.

In order to analyze this phenomenon, I assume in this paper that the main motivation of the Chinese government to impose a narrative on the origins of Sars-Cov-2 is its desire to both maintain and increase its political legitimacy. I propose therefore that the actions taken by the government, including the communication strategy, have the ultimate goal of ensuring political cohesion and maintaining a grip on power. I believe that the ultimate goal of the Chinese government when producing its narrative is to project an image of responsible action and effective management of the health crisis. The successful creation of such an image would create and shape favorable public opinion within China towards the measures taken by the CCP in the face of the epidemic. With this in mind, the Chinese government put two different plans into action. Firstly, it disseminated messages based on scientific evidence regarding its responsibility for the origin of the virus. Secondly, and again using the focus of science, it employed a strategy of spreading fake news about its origin.

Based on the theoretical proposal of truth regimes, this article aims to analyze Chinese narratives of the emergence of a new type of coronavirus. In the first section, I analyze the theoretical proposal of Michael Foucault on the relationship 
between scientific knowledge, truth and power. In the second section, I analyze the narrative employed by the Chinese government to impose its truth about the origin of the outbreak, and the Chinese response to it, in two different ways. First, I discuss the allegations about the Chinese government's responsibility for the origin of the virus, and review how it used scientific arguments to refute the allegations. I then move on to analyze how, using a science-based focus, the Chinese authorities attempted to obfuscate the origin of the outbreak by employing fake news. Finally, in the conclusions, I review how the idea of science as a truth knowledge is used by the Chinese government to construct particular viewpoints and thus legitimize their response to the coronavirus pandemic.

Science, truth and COVID-19 in China
Once the severity of the Sars-COV-2 outbreak became apparent, the CCP put in place a series of tough measures designed to control it. The ensuing battle to contain the spread of the virus was waged on two fronts simultaneously. One side of the narrative was concerned with restricting the reach of the virus as much as possible, and in order to achieve this over 40 million people in Hubei province were isolated, economic activities throughout China were paralyzed and classes were suspended at all school levels [Graham-Harrison and Kuo, 2020]. More than forty thousand health professionals were mobilized to the epicenter of the pandemic and two hospitals were built in record time in Wuhan city [Qian et al., 2020; Wang, Zhu and Umlauf, 2020].

The other side of the narrative was intended to inspire confidence in the population that the government had acted correctly in the face of the pandemic, despite initial mismanagement by the local authorities. The central government promoted a logical and rational discourse, intended to construct a truth about the origin of Sars-Cov.2. This discourse included disseminating both scientific facts and fake news simultaneously. With the eruption of an epidemic, one of the first tasks of scientists and doctors, even while they battle to save lives, is to recognize its origins, as this knowledge is critical in the search for a vaccine to inhibit its spread [Amanat and Krammer, 2020].

The actions of the Chinese government therefore were supported by a narrative based on a scientific and rational approach to the pandemic combined with the spread of fake news with "scientific insinuations". This narrative however is neither neutral nor objective. On the contrary, an account appealing to scientific facts is intended to impose a way of looking at reality that presents itself as true and superior to other ways of explaining the world. For this reason, it was necessary to construct a discourse about the origin of the new coronavirus in order to convince the population that the measures taken by the government to overcome it were indeed correct. As this narrative prevailed, the legitimacy of the CCP government grew stronger, and as a result, both scientific evidence-based discourse and fake news served to increase the authority of the Chinese government.

These discourses are in line with certain social practices framed in what Michael Foucault $[1995 ; 2000]$ called a 'regime of truth'. In this case, scientific discourses and social practices benefited the interests of a certain group - the Chinese bureaucratic elite - over other actors in Chinese society. In other words, the Chinese central government imposed a science-based discourse on the handling of the pandemic, and this strengthened the legitimacy of the CCP. At the same time, 
this strategy favored the imposition of social practices aimed at controlling the Chinese population, with the management of the epidemic as justification.

The measures to combat the spread of the virus and the scientific discourse that justified them, are dialectically constructed in a mutually constitutive relationship permitting regimes of truth to be established. The concept of truth regimes emphasizes how social mechanisms and conventions validate knowledge linked to power systems. Based on the theories of Michael Foucault [1995], I affirm that power and knowledge are closely related. Power and knowledge support each other and enjoy a mutually symbiotic relationship. As Devatk [2009] has pointed out, knowledge is never unconditional, and thus it is impossible to separate truth from power; on the contrary, power systems are needed for the production of truth, and, in turn, truth directly engenders power [Foucault, 2000]. If the Chinese government has the "truth" it generates legitimacy and increases its power; at the same time, the material capacities derived from a strong government such as that of China allow for the spread of a discourse considered to be true at both national and international levels.

From this perspective, what in any historical period is regarded as true depends on the social structures and mechanisms that exist to validate particular methods of achieving said truth or believing certain people or institutions to be capable of producing it. In the contemporary world, it is science which is believed to have the capacity to produce the truth, as well as the practices and the methods that it employs [Foucault, 2000]. For this reason, the rationale behind the speeches made by members of the Chinese government, the halo of science used to justify concrete virus-containment proposals, and the international kudos that China could enjoy by demonstrating an efficient response to the pandemic were all measures designed to produce truth. China wanted to be seen as belonging to a select group of countries notable for their advanced scientific knowledge, a group aiming to obtain the virus genome and/or develop an effective mass-immunization vaccine, and by so doing allowing for a truth to be established about the origin of the pandemic and the correct way to control it.

The interaction between science, discourse and legitimacy shapes the mechanisms by which regimes of truth are established, and one of the mechanisms for establishing such regimes is comprised of narratives. These narratives present a scientific vision that promotes a particular way of explaining the world, a vision through which it is affirmed that the actions taken by the Chinese government were correct because they were true. At the same time, these narratives maintain that the actions of the Chinese government are exemplary and, therefore, should be imitated/followed/implemented by those other countries that want to overcome the problems caused by the virus.

Such narratives do not emerge in isolation, or in a social vacuum, but are created by language. Language however, even scientific language, is not neutral because it produces meanings [Hansen, 2014]. Language is not only a means of communication, but a mediator of a series of habits, conventions, values and prejudices that allow us to make sense of the world [Devatk, 2009]. People do not have immediate access to the world, because as subjects, our relationship with objects is mediated by a sequence of discourses in a relationship that is not transparent because it does not communicate the "reality" of the object to the subject [Huysmas, 2007]. 
The scientific narrative is a particular type of discourse which refers to a specific series of representations and practices through which meanings are produced, identities constituted, social relationships established, and political and ethical goals achieved [Campbell, 2013]. Many discourses are socially silenced, subdued, or simply forgotten, while others are privileged and consequently become dominant. Today, in our contemporary society, scientific discourse is dominant. It is in this sense that Foucault reminds us that [2002]: “... in every society the production of discourse is simultaneously controlled, selected and redistributed by certain numbers of procedures whose function is to combine their powers and dangers, to dominate the random event and dodge its heavy and fearsome materiality" (p. 14).

The narrative is central not to the understanding of an event but to actually constituting it as an event [Campbell, 1998]. Scientific discourse, like any other type of discourse, is not only produced by individuals but is largely inherited, which implies that this discourse is constituted intersubjectively. In other words, it is embedded and constituted within forms of interaction in a broad social context [Huysmas, 2007]. Within these social interactions, the production of a type of knowledge embedded in particular narratives is one of several methods of establishing a regime of truth.

For Foucault [1995] what we consider to be true is something produced from multiple forms of restriction. In addition, the truth frequently has consequences for power. Each society has its regime or "general policy" of truth. This refers to the types of discourse that are accepted and made to function as true; the mechanisms and instances that allow each person to distinguish between true and false statements, how each one is sanctioned, the techniques and procedures that give value in the acquisition of truth, and the situation of those who are in charge of saying what is considered as true [Rabinow, 1984].

"Truth regimes" are a consequence of the discourse and institutions that support them, and are constantly reinforced and redefined through the educational system, the media and the dissemination of political and economic ideologies. In this sense, the "battle for the truth" is not one for some absolute truth that can be discovered and accepted but rather a battle over the rules governing how truth and untruth are separated. This is a battle over the state of truth, and with it, the economic and political role that said truth plays in a given social context [Rabinow, 1984]. As the case of China shows, in the face of the serious health crisis experienced as a result of the expansion of SARS-Cov-2, the speeches promoted as true by the leaders of the state do not simply seek more efficient methods to combat the new disease, but are intended to construct truths that impact the legitimacy of the government's actions in the face of the pandemic.

The scientific discourse on China's role in the emergence and containment of the pandemic therefore aims to generate legitimacy for the Chinese government by striving to establish a truth regime through the promotion of a particular vision of government. With this in mind, the following section analyzes the importance of the narrative regarding the origin of the virus. 
The other battle: the fight to win the international narrative

\subsection{China, the origin of the virus, and the scientific arguments}

Scientific evidence indicates that SARS-CoV-2 is not an artificial virus, but has arisen through a process of natural selection from other viruses of the betacoronavirus genus within the coronaviridae family [Payne, 2017]. Its genome shows different percentages of sequence similarity with the other six known human coronaviruses, and analyses of genome sequences show that, like the other human coronaviruses, SARS-CoV-2 is also of animal origin [Scripps Research Institute, 2020]. This virus represents a new case of zoonosis, that is, an infection produced through a "host jump" of the pathogen from another animal species to ours [Ye et al., 2020]. These mutations, and particularly the insertion of four amino acids into a specific location in the structure of the genome, could not have been predicted by any scientist based on previously known genomic data [Andersen et al., 2020]. The SARS-CoV-2 genome therefore lacks the "traces" that the techniques used to genetically engineer a virus would leave behind [Briones and Peretó, 2020].

Despite this evidence, as COVID-19 has expanded beyond China and become a once-in-a-century pandemic, numerous voices have suggested that China bears huge responsibility for the emergence of SARS- CoV-2. These voices have raised several questions about the new coronavirus. Was SARS-CoV-2 intentionally created? Did it escape from a laboratory due to human error? Was it released intentionally? Was the virus originally created with the intention of building a biological weapon? Did the virus pass from animals to humans because of the gastronomic customs of Chinese people? Those raising these questions believed that the true origin of the virus was not in fact the city's fish and seafood market, but the Wuhan Institute of Virology, located just two kilometers away from it.

The battle to win the narrative about how the Chinese government acted to contain the epidemic and its possible responsibility for the origin of the virus occurs in a broader context of the confrontation between China and the United States. This confrontation escalated with the election of President Donald Trump. An 18-month trade war, recriminations over civil liberties, and conflicts about Beijing's claims to areas of the South China Sea were only some of the areas of friction. The situation therefore escalated from a tit-for-tat trade war between the two nations to an accusation of Chinese responsibility for the origin of the pandemic and recriminations about the poor management of it. Tensions even rose to such a level that in Missouri, legal counsel for the attorney general filed a lawsuit in federal court seeking to hold Beijing and the Chinese Communist Party responsible for the pandemic [Johnson, 2020].

The U.S. call to clarify the origin and spread of the virus has had international impact, and was behind European Union demands for an independent investigation [Connolly, 2020], with countries such as Australia following suit [Karp and Davidson, 2020]. At their heart, these demands reflect suspicion of the Chinese government due to the lack of transparent information. The doubts that have arisen relate to whether the Chinese government withheld information about the severity of the disease and whether it failed to report all the patients and all the deaths associated with it. However, at the same time, the WHO recognized China's handling of the crisis as exemplary, which resulted in the United States government ending its relationship with the organization. 
It was in this context that the Chinese government undertook a series of charm offensives with a view to winning the approval of the international community. Some of these measures involved donating medical equipment to deal with the pandemic and sending specialized doctors to support the efforts of other countries to stop the spread of the virus. The Chinese media recounted the efforts and sacrifices of the Chinese people to help other countries by saving them time before the pandemic spread, with the nation using its embassies to disseminate news or answer questions about Chinese actions and share progress about what was known of the virus, including its genomic sequence. China also defended multilateralism as the best way to contain the pandemic in forums such as the G20, promising that if a vaccine for the virus were developed in China, it would be used for the global public good.

Among the actions taken by the Chinese government, the attempt to determine the origin of the virus was particularly noteworthy. Discovering where the virus came from is essential because of the multiple conspiracy theories that emerged along with the epidemic, and the spread of claims that the virus was intentionally created by the Chinese government to advance its long-held ambition for world domination.

Science-based arguments by the Chinese government play a fundamental role in answering these questions. Relying on science as a criterion of truth theoretically allows a "neutral", "objective" and "rational" approach to the facts, unlike other actions that may simply be seen as propaganda. If the scientific argument therefore can be proven, it may well act to strengthen Chinese legitimacy and leadership, as in contemporary society scientific knowledge is regarded as superior knowledge. The appeal of scientific knowledge as true however did not prevent the Chinese government from using fake news, cloaked with a veneer of science, to establish the Chinese government's version of the truth about the origin of the virus. This being the case, it is important to challenge science as a superior form of knowledge.

\subsection{The use of scientific knowledge to build a convincing narrative}

Allegations that the Chinese government was responsible for the emergence of Sars-Cov-2 were denied by the Chinese official media through an appeal to scientific knowledge. The official media reproduced the opinions of scientists, referred to the information published in prestigious international journals, and constructed arguments based on scientific reasoning.

The first step was to make it appear that the Chinese government was open to any investigation, as maintained by Chinese foreign ministry spokesperson Hua Chunying. Hua stated that China would support a review of the outbreak and pointed out that China has supported the work of the WHO and worked with it an open, responsible and transparent manner" [Zhang, 2020]. At the same time, a Chinese diplomatic offensive was launched to support the argument for allowing scientists, not politicians, to determine the origin of the virus. This was the line taken by Minister Chen Wen of the Chinese Embassy in London when faced with the accusation that the virus may be lab-created. Chen highlighted a WHO report compiled by 27 scientists which maintained that, based on all the evidence, the virus was animal in origin [Embassy of the People's Republic of China in the United Kingdom, 2020]. 
A second step was to present data, assumptions, and opinions of experts from the scientific community. A news story published by the Xinhua agency presented the reasoning of Dr. Zhao Guoping, an academician of the Chinese Academy of Sciences. The subject of the article was the difficulty involved in identifying the source of a new virus due to the significant challenge involved in pinpointing the natural host. To illustrate the point, the article highlighted the obstacles which had to be overcome in the search for the natural host of the SARS virus, stating that it took 13 years after the outbreak of SARS for the species of origin to be identified. The effort to identify the natural host involved the discovery of significant scientific evidence, including biological evidence provided by etiology, clinical medicine and epidemiology, with the genetic sequence being revealed by molecular biology [Xinhua, 2020a].

The WHO issued a widely-disseminated statement through its spokesperson, Fadela Chaib, maintaining that all existing evidence suggested that the virus was of animal origin and "not manipulated or constructed in a lab or anywhere else". Anthony Fauci, director of the U.S. National Institute of Allergy and Infectious Diseases, stated "If we look at the evolution of the virus in bats and what's out there now, the scientific evidence is very, very strongly inclined to show this could not have been artificially or deliberately manipulated" [Xinhua, 2020d]. The China Global Television Network showed an interview with Yuan Zhiming, the director of the Wuhan lab, denying any link between the virus and his facility, with Xinhua news quoting Dr. Gauden Galea, WHO Representative in China, as saying that several researchers who have observed the genomic features of the virus have found no evidence to support that Sars-Cov-2 was artificially constructed [Xinhua, 2020a].

Another way of using scientific knowledge to build a convincing strategy was to appeal to authoritative journals in the field. An article released by the Global Times highlighted research published on the Current Biology website, with the newspaper highlighting that the paper was written by international scientists from the University of Shandong, Xishuangbanna Tropical Botanical Gardens, and the University of Sydney. The news article states: “New research into the characteristics of a recently-identified bat coronavirus, the closest relative of the novel coronavirus, also features the insertion of multiple amino acids, suggesting that seemingly unusual insertion events can occur naturally in coronavirus evolution" [Global Times, 2020].

Xinhua references an article published in The Lancet, an authoritative British medical journal, which states that, based on the phylogenetic analysis of the ten 2019-nCoV genome sequences from nine confirmed Wuhan patients, the virus is a completely new human-infecting coronavirus, with bats the most likely original host [Xinhua, 2020d]. Xinhua also refers to a joint statement published by the Lancet, which overwhelmingly concluded that COVID-19 originated in wildlife, as have so many other emerging pathogens. Xinhua emphasizes that the document was countersigned by 27 leading medical experts from eight countries, indicating that scientists have analyzed genomes of SARS-CoV-2 internationally, and their published results overwhelmingly conclude that the coronavirus originated in wildlife [Xinhua, 2020b]. Finally, Xhinhua identified "five prominent scholars from the U.S., the U.K. and Australia" in the Journal of Nature Medicine, who stated that SARS-CoV-2 is not a laboratory construct or a purposefully manipulated virus [Xinhua, 2020b]. 


\subsection{The spread of Chinese-style fake news: the origin of the virus}

The critical and gradually contentious role of science and technology in modern society has given rise to an excess of scientific and public controversies over scientific and technical issues [Martin and Richards, 1995]. However, in recent years, scientific controversies have been created to promote or delay public policy by announcing that there is an ongoing debate about a matter for which there is actually an overwhelming scientific consensus [Ceccarelli, 2011]. On the other hand, scientific controversies are often intertwined with social controversy; in consequence, the outcome of debates may differ from place to place depending on the contingencies of scientific and social power [Martin, 2008]. In this way, creators of controversy can turn certain scientific ideals, as to be egalitarian and open-minded, to their own advantage [Harker, 2015].

At the same time, scientific controversies have been used to disseminate fake issues, controversies built from scientific arguments to discredit people or institutions. An example is the controversies about climate change. Global warming is a physics problem but climate debate has spread far beyond the limits of the scientific circles and into the media and public sphere, and now is an issue highly politicized [Sherwood, 2011]. On other occasions, as Oreskes and Conway [2010] have noted, scientific debate has been manipulated with the intention to benefit the tobacco industry. In the end, it is necessary to comprehend the communication of the scientific knowledge and the scientific debate, as something beyond just a transmission of messages: "people's consumption of news and information is, first and foremost, a way to reaffirm their affinity with a larger dramatic narrative about the world and their place in it, and transcends facts and figures" [Wardle and Derakhshan, 2018, p. 79]. A world marked characterized by 'the rise of the misinformation society" [Pickard, 2016], new technology makes the manipulation and production of content simple, including the promotion of scientific controversies, and social networks intensely amplify lies peddled by States, populist politicians, and dishonest corporate entities [Ireton and Posetti, 2018].

In this context, the denial that Sars-Cov-2 was created in a laboratory in China was complemented by a fake news propaganda strategy designed to present a narrative in which China ceased to be responsible for the virus and was instead the victim of shadowy foreign forces. As this version spread throughout China, the CCP increased its legitimacy and government incompetence in the early days of the outbreak was forgotten.

The process of building an alternate version of the origin of the virus consisted of three phases. First, the possibility that the virus originated in China was denied through an appeal to scientific criteria mixed with inferences and the opinions of national and international experts. Secondly, it was suggested that the virus could have originated in the United States. The final phase consisted of the dissemination of these ideas through both state media and the social media accounts of Chinese officials in order to lend credibility to this possibility, with users of Chinese networks dedicating themselves to consuming these versions and further disseminating them. Thus, a politically correct truth about the origin of the virus was created, granting greater legitimacy to the CCP and dovetailing with Foucault's theory of the relationship between power and knowledge. 
The Xinhua agency even went so far as to publish a video on its Facebook page entitled "Tracing the origin of COVID-19: facts you need to know". Where did COVID-19 originate? The pieces of the puzzle have yet to come to light." The video starts by highlighting that according to an article published in the journal Science, the Sars-Cov-2 virus did not originate in the Wuhan market. This is followed by the testimony of Dr. Giuseppe Remuzzi, who states that the virus was probably circulating in Italy in early November, with other later testimonies noting the possibility of hundreds of people who had not traveled to China having been infected with what could have been COVID-19 in Florida during December [Xinhua, 2020c]. ${ }^{1}$

In an article published in the People's Daily, entitled "Japanese TV report sparks speculation in China that COVID-19 may have originated in the U.S.", it was reported that, according to Japanese TV, it was likely that some of the 14,000 Americans reported as having died of influenza could have succumbed to coronavirus. The same source speculated that U.S. delegates attending the World Military Games held in Wuhan in October could have brought the coronavirus to the city, where a more deadly and contagious mutation occurred, causing a widespread outbreak [People Daily, 2020]. ${ }^{2}$ On March 4, the People's Daily's reprint of this piece was used as the basis for an article published on the GlobalResearch.ca website, entitled "China's Coronavirus: A Shocking Update. Did the Virus Originate in the U.S.?" It was noted that according to scientific reports, the virus outbreak had started much earlier, probably in November, and that this was shortly after a delegation from the U.S. had attended the Wuhan Military Games. The article further speculated that the origin was not the Wuhan market or even China, but, "according to reports in Japanese", the United States, and also went on to claim that although the virus was first discovered in China, it did not necessarily originate there. ${ }^{3}$

The Global Times challenged the U.S. government to disclose the health and infection information of the U.S. Military World Games delegation which had participated in Wuhan in October, in order to end the conjecture about U.S. military personnel bringing COVID-19 to China. The newspaper affirmed: "An American journalist claimed one U.S. military athlete in the delegation could be patient zero for the deadly new disease. George Webb, an investigative journalist in Washington DC, claimed in recent videos and tweets that he believes Maatje Benassi, a cyclist and armed diplomatic driver who attended the cycling competition in the Games and who was in Wuhan in October, could be the city's COVID-19 patient zero." [Shumei and Lin, 2020].

This information was disseminated through the Chinese state press and their Facebook and Twitter accounts as well as the social media accounts of public officials. Disinformation was also spread by diplomats and spokespersons from the

\footnotetext{
${ }^{1}$ This video can be consulted on the Facebook page of the Xinhua news agency on this link: https: / www.facebook.com/XinhuaNewsAgency/videos/251741492837106/.

${ }^{2}$ The news was originally published in Global Times. However, this news was broadcast by other Chinese media such as People Daily. It is currently available at: http:/ / en.people.cn/n3/2020/0223/c90000-9661026.html.

${ }^{3}$ Although this article is not available on the original version in GlobalResearch website or on the Global Times website, it can still consult on other websites like the International Movement For A Just World (Available at: https:/ / www.just-international.org/articles/chinas-coronavirus-a-shockingupdate-did-the-virus-originate-in-the-us/).
} 
Ministry of Foreign Affairs. Other high-ranking Chinese bureaucrats have, in turn, advanced conspiracy theories about the origins of COVID-19, with Foreign Ministry spokesman Lijian Zhao tweeting a link to an article that falsely claimed the virus had originated in the United States, and which was later retweeted from the official Twitter account of the Chinese embassy in South Africa. According to Boxwell [2020] Global Times has 1.7 million followers on Twitter; China Xinhua News, 12.6 million; The People's Daily, 7.1 million; China Daily, 4.3 million; and China Global Television Network (CGTN), 14 million. Zhao Lijian, a spokesperson at the information department of the Ministry of Foreign Affairs', had 287,000 followers when he tweeted a link to a conspiracy website alleging the U.S. was responsible for the virus.

Another way to spread the Chinese version of events related to the origin of Sars-Cov-2 is through media alliances or the direct purchase of space from international news networks. Freedom Press reports that foreign news outlets have continued to accept payments from Chinese state media to spread propaganda about the Chinese response to COVID-19. The Economist, Wall Street Journal, and The Telegraph are among the foreign media that have published articles as paid advertisements in the past two months. The official Xinhua News Agency has also used content-sharing partnerships with African news websites such as News Ghana to highlight Chinese assistance against COVID-19 in various countries. In addition, Chinese state media has been paying for political advertisements on foreign social media sites in order to cast blame on the United States for the pandemic. This information has been published on both Facebook and Instagram without warnings to readers about the origin or veracity of the information. The ads promote content about China's handling of COVID-19 and are produced by Chinese state-run media outlets, including Xinhua, China Central Television, and the Global Times [Cook, 2020].

\section{Conclusions}

As a result of the significant challenge presented by the emergence of COVID-19, the Chinese government has faced in-depth questioning about its ability to adequately manage the situation. This questioning could directly throw into question the legitimacy of Communist Party rule in China. As a way of managing the crisis, in addition to taking measures to contain the virus and with a view to creating an appropriate environment for caring for those affected, the CCP devised a strategy to make its version of the truth about the origin of the virus the generally accepted story. With this intention, both state media and public officials generated discourses, based on scientific argumentation, with the aim of presenting them as superior and true.

How the origin of the virus should be determined was no small matter, with it ultimately being decided that science should be used to reinforce the official version of events. There were two reasons for this: on one hand, it could be shown that the virus had not been created in a laboratory, and that the Chinese population, like that of the rest of the world, had been victims of a new disease arising from a process of a natural evolution. On the other hand, it would demonstrate the willingness of the Chinese government to collaborate with the world in the search to find a global solution to the pandemic. Finally, a science-based approach would topple conspiracy theories and quash claims by American politicians that the virus 
had been intentionally created as part of a complex Chinese strategy to achieve world domination.

These discourses, having scientific information as supporting truth-criteria, sought to reach a "neutral", "objective" and "rational" approach to the facts. By establishing science as the criterion of truth, Chinese legitimacy and leadership would be strengthened. This is possible because in our contemporary society, as Foucault warned, scientific knowledge has been accepted as superior knowledge and enjoys elevated status, and this is something that should be challenged. The Chinese government used both a science-based narrative and fake news, cloaked in a veil of science, to establish the origin of the virus.

The discourses on the true origin of COVID-19 demonstrate the close relationship between knowledge and power. On the one hand, a true and scientific discourse strengthened the credibility of the Chinese government and the action it took to contain the pandemic, lending it greater prestige and legitimacy. In turn, power - the enormous machinery of Chinese media and the bureaucratic structure of the $\mathrm{CCP}$ - enabled and promoted the generation and dissemination of these messages. This case shows that science, although generally accepted as rational knowledge based on verifiable facts and honest intellectual debate, can still be used and manipulated by governments as a tool to consolidate their hold on power, and that the Chinese government is well aware of this.

It is obvious that this manner of proceeding is not exclusive to the Chinese government. Many other governments have used supposedly scientific information to strengthen their legitimacy in the context of the political crisis caused by the outbreak. Even, some of these governments were democratically elected and their countries have robust democratic institutions. However, a widely spread attitude is that scientific knowledge is used to generate false narratives about the origin of the virus, its social impact and how to contain it. Politicians use science for their personal or collective benefit. Political factions use scientific knowledge to consolidate their power or try to undermine the power of their adversaries. On the other hand, the public policies implemented to combat the virus are not necessarily based on solid scientific knowledge. However, using science as a source of legitimacy for political power represents a critical long-term problem. To the extent that the false narratives based on some scientific data about COVID-19 collapses, the prestige of science and the scientific community will also collapse. In this sense, science could be considered as one more activity, among many others. The risk is that the construction of scientific arguments would be abandoned as the best way to debate public affairs, renouncing reason as the best way to settle our differences, build a more inclusive society and generate better life prospects for most of the world population. At the end of the day, what it is urgent to battle is not scientific knowledge but the inappropriate use of scientific knowledge to build regimes of truth that respond to the interests of a privileged minority.

References

Amanat, F. and Krammer, F. (2020). 'SARS-CoV-2 vaccines: status report'. Immunity 52 (4), pp. 583-589. https://doi.org/10.1016/j.immuni.2020.03.007.

Andersen, K. G., Rambaut, A., Lipkin, W. I., Holmes, E. C. and Garry, R. F. (2020).

'The proximal origin of SARS-CoV-2'. Nature Medicine 26 (4), pp. 450-452.

https://doi.org/10.1038/s41591-020-0820-9. 
Bloomberg (20th January 2020). 'China will rack up three billion trips during world's biggest human migration'. Bloomberg News.

URL: https://www . bloomberg. com/news/articles/2020-01-20/china-readie s-for-world-s-biggest-human-migration-quicktake.

Boxwell, R. (4th April 2020). 'The blame game: the origins of COVID-19 and the anatomy of a fake news story'. South China Morning Post.

URL: https://www.scmp.com/magazines/post-magazine/long-reads/article /3078417/how-chinas-fake-news-machine-rewriting-history.

Briones, C. and Peretó, J. (21st April 2020). 'El origen del coronavirus SARS-CoV-2, a la luz de la evolución'. The Conversation.

URL: https://theconversation.com/el-origen-del-coronavirus-sars-cov2-a-la-luz-de-la-evolucion-136897.

Campbell, D. (1998). National deconstruction: violence, identity and justice in Bosnia. Minneapolis, MN, U.S.A.: University of Minnesota Press.

URL: https://www . jstor.org/stable/10.5749/j . cttttwr8.

- (2013). 'Poststructuralism'. In: International relations theory: discipline and diversity. Ed. by T. Dunne, M. Kurki and S. Smith. Oxford, U.K.: Oxford University Press, pp. 223-246.

Ceccarelli, L. (2011). 'Manufactured scientific controversy: science, rhetoric and public debate'. Rhetoric E Public Affairs 14 (2), pp. 195-228. https://doi.org/10.1353/rap.2010.0222.

Connolly, A. (6th May 2020). 'E.U. members to push for formal probe into coronavirus origins, Canadian position unclear'. Global News. URL: https : //glo balnews .ca/news/6911414/who-coronavirus-pandemic-investigation/.

Cook, S. (20th April 2020). 'Beijing's coronavirus propaganda has both foreign and domestic targets'. Freedom House. URL: https://freedomhouse . org/article/be ijings-coronavirus-propaganda-has-both-foreign-and-domestic-targets.

Davidson, H. (20th March 2020). 'Chinese inquiry exonerates coronavirus whistleblower doctor'. The Guardian.

URL: https://www . theguardian.com/world/2020/mar/20/chinese-inquiry-e xonerates-coronavirus-whistleblower-doctor-li-wenliang.

Devatk, R. (2009). 'Post-structuralism'. In: Theories of international relations. Ed. by S. Burchill and A. Linklater. New York, NY, U.S.A.: Palgrave McMillan, pp. 183-211.

Embassy of the People's Republic of China in the United Kingdom (26th April 2020). 'Minister Chen Wen gives live interview on "World at One" of BBC Radio 4'. Embassy News.

URL: http://www . chinese-embassy . org . uk/eng/EmbassyNews/t1774381.htm.

Foucault, M. (1995). Discipline \& punish: the birth of the prison. New York, NY, U.S.A.: Vintage Books.

- (2000). Power: essential works of Foucault 1954-1984. New York, NY, U.S.A.: The New Press.

- (2002). El orden del discurso. Barcelona, Spain: Tusquets Editores.

Global Times (14th May 2020). 'Discovery of close relative of novel coronavirus offers evidence of its natural origin'. Global Times.

URL: https://www.globaltimes.cn/content/1188335. shtml. 
Graham-Harrison, E. and Kuo, L. (19th March 2020). 'China's coronavirus lockdown strategy: brutal but effective'. The Guardian.

URL: https://www . theguardian . com/world/2020/mar/19/chinas-coronaviru s-lockdown-strategy-brutal-but-effective.

Hansen, L. (2014). 'Post-structuralism'. In: The globalization of world order: introduction to international relations. Ed. by J. Baylis, S. Smith and P. Owens. Oxford, U.K.: Oxford University Press, pp. 169-183.

Harker, D. (2015). Creating scientific controversies: uncertainty and bias in science and society. Cambridge, U.K.: Cambridge University Press. https://doi.org/10.1017/cbo9781107706903.

Huysmas, J. (2007). 'James Der Derian: the unbearable lightness of theory'. In: The future of international relations. Ed. by I. B. Neumann and O. Waever. New York, NY, U.S.A.: Routledge, pp. 361-387. https://doi.org/10.4324/9780203993620.

Ireton, C. and Posetti, J. (2018). 'Introduction'. In: Journalism, 'fake news' \& disinformation. Ed. by C. Ireton and J. Posetti. Paris, France: UNESCO, pp. 14-25. URL: https://en . unesco.org/fightfakenews.

Johnson, K. (24th April 2020). 'Missouri opens up a new front against China in coronavirus blame game'. Foreign Policy.

URL: https: //foreignpolicy.com/2020/04/24/missouri-opens-up-a-new-fr ont-against-china-in-coronavirus-blame-game/.

Karp, P. and Davidson, H. (29th April 2020). 'China bristles at Australia's call for investigation into coronavirus origin'. The Guardian.

URL: https://www . theguardian.com/world/2020/apr/29/australia-defends -plan-to-investigate-china-over-covid-19-outbreak-as-row-deepens.

Lam, W. (2019). 'Xi Jinping warns against the "black swans" and "gray rhinos" of a possible color revolution'. China Brief: A Journal of Analysis and Information 19 (5), pp. 6-9. URL: https://jamestown.org/wp-content/uploads/2019/03/Read-th e-03-05-2019-CB-Issue-in-PDF1.pdf.

Li, Y. (22nd January 2020). 'China silences critics over deadly virus outbreak'. The New York Times.

URL: https://www . nytimes . com/2020/01/22/health/virus-corona.html.

Martin, B. (2008). 'The globalisation of scientific controversy'. Globalization 7 (1). URL: http://globalization.icaap.org/content/v7.1/Martin.html.

Martin, B. and Richards, E. (1995). 'Scientific knowledge, controversy and public decision-making'. In: Handbook of science and technology studies. Ed. by G. E. Markle, J. C. Petersen and T. Pinch. Newbury Park, CA, U.S.A.: Sage, pp. 506-526. https://doi.org/10.4135/9781412990127.d30.

Oreskes, N. and Conway, E. (2010). Merchants of doubts: how a handful of scientists obscured the truth on issues from tobacco smoke to global warming. London, U.K.: Bloomsbury Press.

Payne, S. (2017). 'Family coronaviridae'. In: Viruses: from understanding to investigation. The Netherlands: Elsevier, pp. 149-158. https://doi.org/10.1016/b978-0-12-803109-4.00017-9.

People Daily (23rd February 2020). 'Japanese TV report sparks speculations in China that COVID-19 may have originated in U.S.' People Daily. URL: http://en. people.cn/n3/2020/0223/c90000-9661026.html. 
Pickard, V. (2016). 'Media failures in the age of Trump'. The Political Economy of Communication 4 (2), pp. 118-122.

URL: https://www . polecom.org/index.php/polecom/article/view/74/264.

Qian, X., Ren, R., Wang, Y., Guo, Y., Fang, J., Wu, Z.-D., Liu, P.-L. and Han, T.-R. (2020). 'Fighting against the common enemy of COVID-19: a practice of building a community with a shared future for mankind'. Infectious Diseases of Poverty 9 (1), 34. https://doi .org/10.1186/s40249-020-00650-1.

Rabinow, P. (1984). 'Introduction'. In: The Foucault reader: an introduction to Foucault's thought. Ed. by P. Rabinow. London, U.K.: Penguin, pp. 3-29.

Rezková, A. and Šimalčík, M. (30th March 2020). 'Oxford-style debate: COVID-19 epidemic as China's 'Chernobyl moment'?' Oxford Debates.

URL: https://chinaobservers . eu/oxford-style-debate-impact-of-epidemi c-response-on-ccps-legitimacy/.

Scripps Research Institute (17th March 2020). 'COVID-19 coronavirus epidemic has a natural origin'. ScienceDaily.

URL: https://www . sciencedaily . com/releases/2020/03/200317175442 .htm.

Sherwood, S. (2011). 'Science controversies: past and present'. Physics Today 64 (10), pp. 39-44. https://doi.org/10.1063/pt.3.1295.

Shumei, L. and Lin, W. (25th March 2020). 'U.S. urged to release health info of military athletes who came to Wuhan in October 2019'. Global Times. URL: https://www . globaltimes.cn/content/1183658. shtml.

Szabo, L. (14th February 2020). 'Facts vs. fears: five things to help weigh your coronavirus risk'. Kaiser Health News. URL: https://khn.org/news/facts-vs-f ears-five-things-to-help-weigh-your-coronavirus-risk/.

Tian, W. L. and Lee, S. E. (10th March 2020). 'Xi visits Wuhan, signaling tide turning in China's coronavirus battle'. Reuters. URL: https://www. reuters . com/articl e/us-health-coronavirus-china/xi-visits-wuhan-signaling-tide-turnin g-in-chinas-coronavirus-battle-idUSKBN20X01F.

Wang, J., Zhu, E. and Umlauf, T. (6th February 2020). 'Coronavirus hospitals in just over a week'. The Wall Street Journal. URL: https://www.wsj .com/articles/how -china-can-build-a-coronavirus-hospital-in-10-days-11580397751.

Wardle, C. and Derakhshan, H. (2018). Information disorder: toward an interdisciplinary framework for research and policymaking. Strasbourg, France: Council of Europe. URL: https://rm. coe. int/Report-D/09000016807bf5f6.

World Health Organization (2020). Naming the coronavirus disease (COVID-19) and the virus that causes it. URL: https://www . who. int/emergencies/diseases/nove 1-coronavirus-2019/technical-guidance/naming-the-coronavirus-diseas e- (covid-2019)-and-the-virus-that-causes-it.

Xinhua (20th May 2020a). 'News analysis: why is coronavirus origin tracing a challenging task for scientists?' Xinhunet. URL: http://www. xinhuanet.com/english/2020-05/20/c_139072317.htm.

- (10th May 2020b). 'Reality check of U.S. allegations against China on COVID-19'. Xinhunet.

URL: http: //www . xinhuanet. com/english/2020-05/10/c_139044103.htm.

- (19th May 2020c). Tracing origin of COVID-19: facts you need to know. [Facebook video]. URL: https://www. facebook. com/XinhuaNewsAgency/videos/25174149 $2837106 /$. 
Xinhua (11th May 2020d). 'Xinhua headlines: truth in China's pandemic battle smashes absurd U.S. allegations'. Xinhunet.

URL: http://www . xinhuanet.com/english/2020-05/11/c_139045957.htm.

Ye, Z.-W., Yuan, S., Yuen, K.-S., Fung, S.-Y., Chan, C.-P. and Jin, D.-Y. (2020). 'Zoonotic origins of human coronaviruses'. International Journal of Biological Sciences 16 (10), pp. 1686-1697. https://doi.org/10.7150/ijbs. 45472.

Zhang, P. (7th May 2020). 'China backs WHO investigating origin of COVID-19, hits out at U.S. 'politicising issue". South China Morning Post.

URL: https://www . scmp.com/news/china/diplomacy/article/3083372/china -backs-who-investigating-origin-covid-19-hits-out-us.

Author

Daniel Lemus-Delgado. He is a professor at the School of Social Sciences and Government, Tecnológico de Monterrey, Mexico. He is a member of the National System of Researchers, Mexico (Level II). He has been a Visiting Scholar at Fudan University, China. Among his lines of research is the Foreign Policy of the People's Republic of China. ORCID: 0000-0003-1002-5319. E-mail: dlemus@tec.mx.

\section{How to cite}

Lemus-Delgado, D. (2020). 'China and the battle to win the scientific narrative about the origin of COVID-19'. JCOM 19 (05), A06.

https://doi.org/10.22323/2.19050206. 